\title{
Association between Patient's Educational Degree with Level of Knowledge and Perception Regarding Pulmonary Tuberculosis
}

\author{
Mohammad Subkhan', Rahmat Sayyid Zharfan ${ }^{1}$, Ricky Indra Alfaray ${ }^{2,3}$, Kamal Musthofa ${ }^{1}$ \\ ${ }^{1}$ Lecture, Faculty of Medicine, Universitas Muhammadiyah Surabaya, Surabaya, Indonesia, ${ }^{2}$ Student, Graduate \\ School of Medicine, Oita University Japan, ${ }^{3}$ Postgraduate, Faculty of Medicine, Universitas Airlangga, Surabaya, \\ Indonesia
}

\begin{abstract}
Background: Indonesia is the second largest population of pulmonary tuberculosis (TB) worldwide. Unfortunately, this condition has remained unchanged past decade. Education is essential for the formation of knowledge and perception, which is important, due to its impact on tuberculosis treatment implementation.

Objective: The aim of this study is to determine the association between patient's educational degree with knowledge and perception regarding pulmonary tuberculosis.

Method: This was observational analytic study with cross-sectional design. The study was conducted on 51 patients in TB outpatient clinic from Siti Khodijah Hospital and two Primary Health Care in Sidoarjo. Using simple random sampling, a questionnaire was formed to obtain related information about the variables studied; including baseline characteristic (age, gender, education, occupation), patient's knowledge, and perception regarding pulmonary tuberculosis. Then parameter's of knowledge and perception were classified: good and low.

Results: Using multivariate analysis of Wilcoxon test, there was a significant difference between each group of patient educational degree with knowledge regarding tuberculosis $(p=0.00)$ and perception regarding tuberculosis $(\mathrm{p}=0.00)$.

Conclusion: Different patient educational degree shows different knowledge and perception regarding Pulmonary TB. This result may indicate that the educational degree affected the patient to understand the disease. The collaborative approach needed to build proper patient's knowledge and perception. Lack of knowledge regarding TB, may due to a deficiency in Indonesian school curriculum content. These results will inform the development of relevant education, and information system, to enhance awareness about tuberculosis in society.
\end{abstract}

Keyword: Education, knowledge, perception, tuberculosis.

\section{Introduction}

Tuberculosis (TB) is one of the leading cause of

\section{Corresponding Author:}

Mohammad Subkhan

Faculty of Medicine, Universitas Muhammadiyah

Surabaya, Jl. Mulyorejo, Dukuh Sutorejo, Mulyorejo,

Surabaya, East Java 60115, Indonesia

e-mail: inatime2019c@gmail.com

Phone: +6231-3811966/+6285331000482 deaths in the world, ranking in the top 10 cause of global death ${ }^{(1)}$. Worldwide, 1 out of 4 people is affected by $\mathrm{TB}^{(2)}$. According to world organization health (WHO), there were 10 million people who suffered from TB, in which 1.6 million of them died because of it in 2017. It was also the leading cause of death in patients with HIV. TB spreads across the globe, but most of TB cases were found in South East Asia and Western Pacific regions (62\% of new cases), followed by African region ( $25 \%$ of new cases) in 2017. The top eight countries with the most new cases in 2017 were India, China, Indonesia, 
the Philippines, Pakistan, Nigeria, Bangladesh, and South Africa ${ }^{(1,2)}$.

Indonesia is the second largest population of pulmonary TB worldwide. In Indonesia itself, according to the Indonesian Health Ministry Center of Data and Information, TB prevalence reached 254 per 100,000 population or 25.4 per $1,000,000$ population in 2017 . In 1992, data from Household Health Survey showed that TB is ranked 2nd as the cause of death in Indonesia. The ministry of health in 2016 has targeted to eliminate TB nationwide in 2035 and its elimination in 2050. The definition of TB elimination is if only 1 per $1,000,000$ population suffers from $\mathrm{TB}{ }^{(3)}$.

Tuberculosis is caused by a bacterial agent named Mycobacterium tuberculosis, an obligate aerobic and slow-growing intracellular parasite (4). Tuberculosis itself has a very long history, dating from 70,000 years ago $^{(5)}$. Robert Koch was the first scientist that was able to isolate the bacteria ${ }^{(6)}$. He then presented his result to the Society of Physiology in Berlin on March 24, 1882(7).

WHO has already declared that TB is a global public health emergency worldwide, thus launched the directly observed treatment short course (DOTS) strategy in $1993^{(1)}$. In 1995, the Indonesian government started to implement DOTS as a part of National Tuberculosis Control Program in several primary health cares, and in 2000 the strategy was conducted nationwide in all health cares, especially in primary health cares ${ }^{(3)}$.

The long term goal of the TB Control Program is to lower the case and deaths that are caused by TB by breaking the transmission chain, thus making it no longer a problem in Indonesia's population. To support this program, surveillance is not enough to control TB. Further analysis towards risk factor of TB transmission is needed to break the transmission chain, regarding the high prevalence of TB cases and its complication and burden towards the population. One of the factors that might contribute towards TB transmission is knowledge and perception about it.

\section{Method}

Study Area and Population: The study was conducted in Sidoarjo Regency, East Java, Indonesia. The region has a total population of 2,279 million, with an estimated area of 634.4 square kilometers. In the region, population density is about 3,089.09 persons/ square kilometer though it varies from zone to zone.
The 2 districts; Taman, and Medaeng, were conveniently selected for a major study of the prevalence of latent and active TB. However, before the implementation of a survey on the prevalence of the disease, we attempted to assess the knowledge and perception of the communities about Lung TB. There was no previous information on the level of pastoral community awareness about Lung TB in the present study areas or the region as a whole. The participants were eligible if they were the patient, a husband/wife (or the responsible person) in the selected households, apparently healthy and willing to volunteer to be interviewed. The study protocol was approved by the Ethical Clearance Committee of the Muhammadiyah University of Surabaya, as well as by the Regional Committee for Medical Research Ethics of Sidoarjo Regency. Each participant was asked to fill the questionnaire independently, and the collected information was kept confidential.

Scope of the discovery of patients with new TB + AFB (Case Detection Rate-CDR) with a target of 70\% and acquisition of $33.15 \%$, up $4.72 \%$ compared to 2014 of $37.87 \%$. The low TB CDR is still low because there are still $25 \%$ of hospitals implementing DOTS; the weak point of the Hospital is connected to the network between health facilities for TB case discovery. For this reason, it is necessary to do a strategy in the future so that the compatibility of the Hospital of Related Points can be obtained, among others, through internal hospital monitoring and evaluation, increasing findings of finding cases for TB case discovery, supported by active promotion to more intensive communities.

The data collected in 2013 found 733 new cases of smear + TB were approved, and completed as many as 624 cases (Cure rate $=85.13 \%$ ), and the results of treatment were complete as many as 54 cases, so the Success Rate $=92.5 \%$, this situation increased compared to 2012 Cure Rate $=82.6 \%$, and Success Rate $=90.88 \%$.

Study Design and Data Collection: This research was conducted at the Primary Health Care of Taman District, and Medaeng District, and Siti Khodijah Hospital, Sidoarjo Regency. This type of research is Analytical Observational with a cross-sectional approach. The population of this study was pulmonary tuberculosis patients at Taman Primary Health Center, Medaeng Health Center, and Siti Khodijah Hospital during February 2019. 
The study sample was all Tuberculosis patients with positive Acid-Fast Stain. The sample was taken by simple random sampling, as many as 51 people. Data collection using a questionnaire. Data were analyzed using the Wilcoxon test.

Structured questionnaires were prepared in language, based on information from the available literature. The questionnaires were translated into language Information on the socio-demographic characteristics of the participants was also included in the questionnaires.

\section{Results}

Based on the age distribution of respondents in this study, it can be seen that the youngest age of the respondents is 21 years, and the oldest is 72 years. The average age of the respondents was 43.39 years, and most respondents were 55 years old, with a standard deviation of 13.6. From the data, it can be seen that the characteristics of respondents based on age grouping are productive age groups (18-49 years). Whereas based on sex, most respondents were male, 29 people $(56.9 \%)$ while women were 22 people (43.1\%).

Based on the educational background of the respondents, most of the respondents in this study had a high school education, amounting to 32 people (62.7\%). Distribution of respondents' education level is in Figure 1.

In determining the level of knowledge in general, the authors did the normality test of data using SPSS. Based on the results of the normality test, the Asymp value is obtained. The sign is 0.000 , so it can be concluded that there are significant differences, in other words, that the data is normally distributed. So to determine the knowledge level cut off point, the researcher uses the median value as a boundary value.

From the questionnaire data, the results show that the middle value of the knowledge level of the respondents is 8. Based on the analysis, the value of 8 is used as the cut of the point. If the score of the respondent's knowledge is equal or more than 8 , the respondent is categorized as knowledgeable, and if the respondent's knowledge score is less than 8 , then the respondent is categorized as lacking knowledge. Distribution of respondents' level of knowledge category in this study in general, as many as 9 respondents (17.6\%) have good knowledge, and 42 respondents $(82.4 \%)$ lack knowledge.
To facilitate understanding of the distribution of knowledge levels according to the characteristics of respondents (age, gender, education, occupation, income and information sources) then the merging of each characteristic is carried out into two parts (good and less knowledge, positive and negative perception). The education group is divided into No schools, elementary, junior high, high schools, and diploma or above. The results of the level of knowledge distribution related to the characteristics of respondents are presented in Figure 1.

Questionnaires related to knowledge about TB disease distributed to respondents consisted of 6 sub-topics, namely risk factors and causes, modes of transmission, symptoms, and self-examination, treatment, and complications. The questions on the questionnaire take the form of true and false statements. The questionnaire statement on each sub-topic is summed and compared between the number of respondents' answers with the correct number of scores, which should then be changed in the form of percentages. Then the percentage is categorized based on the cut of point determined by the author.

Determination of the cut-off point score in the perception category, the author, used the median value as the boundary value. Based on the analysis, the value of 12 is used as the cut off point. If the respondent's perception score is equal or more than 12 , the respondent is categorized as having a positive perception, and if the respondent's perception score is less than 12 then the respondent is categorized as having a negative perception. Distribution of perceptual categories of respondents in this study can be seen as follows. Based on the analysis, it can be seen in general that ten respondents $(19.6 \%)$ had positive perceptions, and 41 respondents $(80.4 \%)$ had negative perceptions regarding TB disease. Using multivariate analysis of Wilcoxon test, there was a significant difference between each group of patient educational degree with knowledge regarding tuberculosis $(\mathrm{p}=0.000)$ and perception regarding tuberculosis $(p=0.000)$.

\section{Discussion}

According to the result of this study, there was a significant difference between each group of patient educational degree with knowledge regarding tuberculosis $(p=0.000)$ and perception regarding tuberculosis $(p=0.000)$. Previous studies were related, 
even though some of them were not directly linked to our study.

Manalu et al. held a survey towards a group of people, where he concluded that several people did not know about free TB treatment in primary health cares. This survey was also supported by another survey about tuberculosis prevalence in 2004 , where $80 \%$ of the participants did not know about free anti TB drug (8). A study by Hoa reported that health education is significantly linked to national TB prevalence in Vietnam ${ }^{(9)}$. A case report in Jakarta, Indonesia on 19961999 concluded that low education is related to lack of knowledge in environmental awareness, represented by the population's behavior to spit sputum wherever they want to ${ }^{(10)}$.

A study from Nurjana concluded that TB cases were found mostly in a low educated population ${ }^{(11)}$. Based on a study in East Timor, a population who did not take any formal education were most likely to drop out from TB treatment ${ }^{(12)}$. Another study that was held in Dompu, a city in West Nusa Tenggara Province, Indonesia showed that participants who had higher education (attended school until high school) were more obedient in TB treatment than participants whom only attended school until elementary school ${ }^{(13)}$.

An epidemiological study involving the population in Europe from 1990 to 2003 showed that educational and socioeconomic inequality contributed to TB deaths in Europe ${ }^{(14)}$. Ratnasari reported that alongside nutritional status and household density, education was one of the factors that can be used to predict TB infection towards the population in the city of Oku, South Sumatra Province, Indonesia $\left.{ }^{(10}\right)$. A study in India also showed the same result, where the population with higher education lower the risk of lung $\mathrm{TB}^{(15)}$.

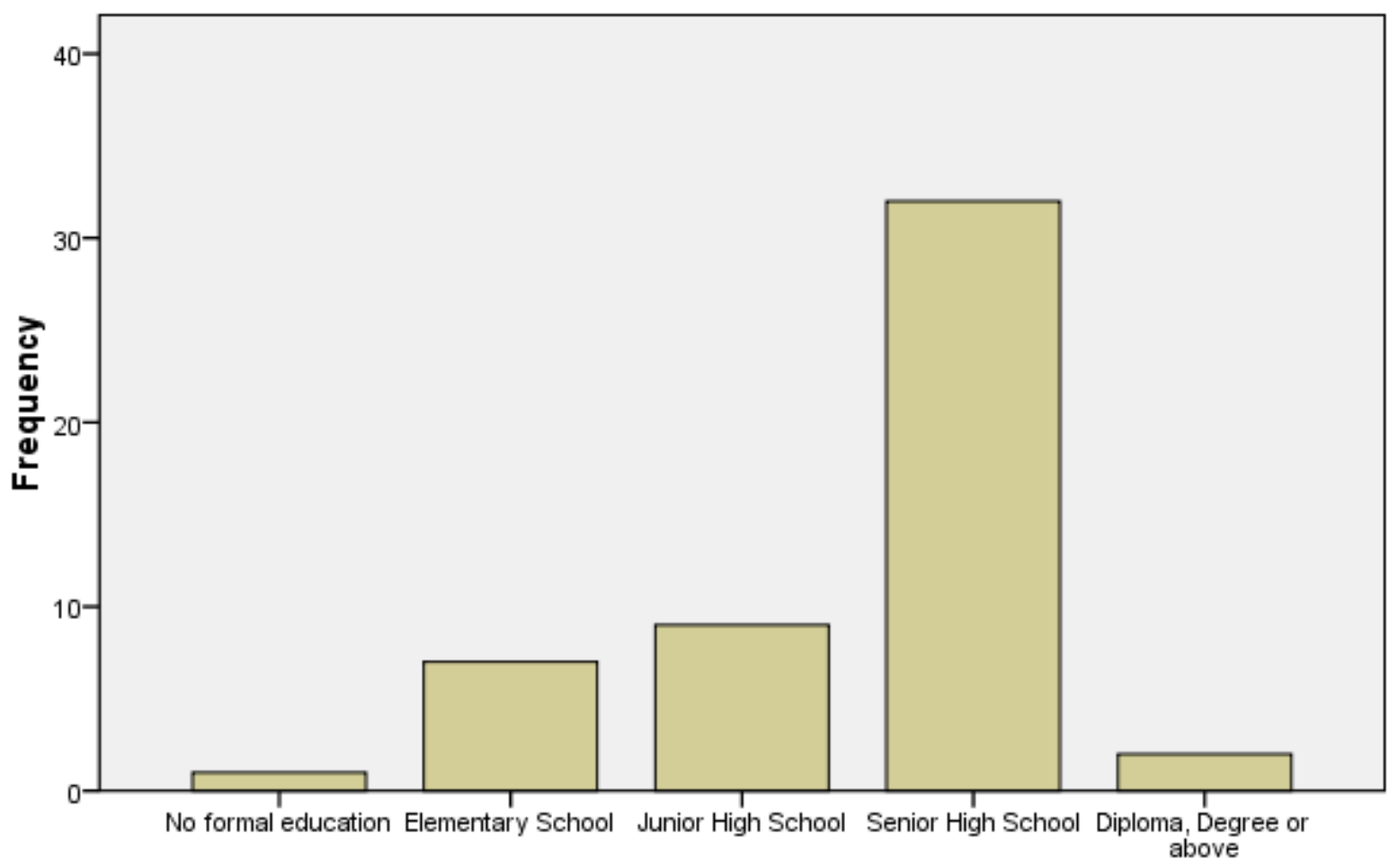

Figure 1. Distribution of Subject's Educational Level

\section{Conclusion}

The level of knowledge and public perception about TB in the work area of the Taman Primary Health Center, Medaeng Primary Health Center, and Siti Khodijah Hospital are still relatively poor. The further finding, there were different finding in the level of knowledge and perception between the group who had a different level of education. This indicates that the level of education should be considered as a valuable factor affecting outcome program which targeting in increasing the level of knowledge and perception in the community. Also, the Primary Health Center and other health workers carry out more detailed counseling (TB 
risk factors, efforts to prevent TB and complications of TB) and reach all levels of society so that information about TB that is owned by the community is uniform so that TB can be controlled. This result may indicate that the educational degree affected the patient to understand the disease. The collaborative approach needed to build proper patient's knowledge and perception. Lack of knowledge regarding $\mathrm{TB}$, may due to a deficiency in Indonesian school curriculum content. These results will inform the development of relevant education, and information system, to enhance awareness about tuberculosis in society.

Conflict of Interest: There is no conflict of interest to declare.

Acknowledgment: The author's thanks Sidoarjo Regency Department of Health for their administrative support and Faculty of Medicine, Universitas Muhammadiyah Surabaya, Surabaya, Indonesia staff and student for their helpful comments, and support regarding the study and manuscript. We would like to express our sincere thanks to the Indonesia Tuberculosis International Meeting (INATIME) event which facilitated us to present this research on 5-7 April 2019 at Surabaya, Indonesia.

\section{Funding: None}

Data Availability: The data set used and/or analyzed during the current study are available from corresponding author on reasonable request.

Ethics Statement: All procedures performed in studies involving human participants were in accordance with the ethical standards of the Ethics Committee in Faculty of Medicine, Universitas Muhamadiyah Surabaya, Surabaya, Indonesia.

\section{Reference}

1. Sotgiu G, Sulis G, Matteelli A. Tuberculosis-a World Health Organization Perspective. Microbiol Spectr. 2017;5(1):10.1128/microbiolspec.TNMI70036-2016.

2. Stewart RJ, Tsang CA, Pratt RH, Price SF, Langer AJ. Tuberculosis - United States, 2017. MMWR Morb Mortal Wkly Rep. 2018;67(11):317-23.

3. Indonesia K. InfoDATIN: Pusat Data dan Informasi Kementerian Kesehatan RI. Jakarta: Kementerian Kesehatan Republik Indonesia. 2014.
4. Herchline T, Trent A. 796. Treatment of Latent Tuberculosis Infection in a Refugee Population. Open Forum Infect Dis. 2018;5(Suppl 1):S286-S.

5. Ribón W. Tuberculosis: expanding knowledge: BoD-Books on Demand; 2015.

6. Gradmann C. Robert Koch and the pressures of scientific research: tuberculosis and tuberculin. Med Hist. 2001;45(1):1-32.

7. Bartolozzi G. Vaccini e vaccinazioni. Terza edizione. Milano: Elsevier; 2012.

8. Manalu HSP. Faktor-faktor yang mempengaruhi kejadian TB paru dan upaya penanggulangannya. Jurnal Ekologi Kesehatan. 2010;9(4 Des).

9. Hoa NP, Diwan VK, Co NV, Thorson AEK. Knowledge about tuberculosis and its treatment among new pulmonary TB patients in the north and central regions of Vietnam. Int J Tuberc Lung Dis. 2004;8(5):603-8.

10. Ratnasari NY. Hubungan dukungan sosial dengan kualitas hidup pada penderita tuberkulosis paru (TB paru) di balai pengobatan penyakit paru (BP4) Yogyakarta unit minggiran. J Tuberkulosis Indones. 2012;8(7):7-11.

11. Nurjana MA. Faktor risiko terjadinya Tuberculosis paru usia produktif (15-49 tahun) di Indonesia. Media Penelitian dan Pengembangan Kesehatan. 2015;25(3):163-70.

12. Da Silva V, Tigeh S, Wirawan N, Bakta M. The relationship between education, job, and family income with TB medication dropouts in TimorLeste. Bali Medical Journal. 2016;5(2):279-82.

13. Erawatyningsih E, Purwanta HS. Faktor-faktor yang mempengaruhi ketidakpatuhan berobat pada penderita tuberkulosis paru. Berita Kedokteran Masyarakat. 2009;25(3):117.

14. Álvarez JL, Kunst AE, Leinsalu M, Bopp M, Strand $\mathrm{BH}$, Menvielle $\mathrm{G}$, et al. Educational inequalities in tuberculosis mortality in sixteen European populations. Int $\mathrm{J}$ Tuberc Lung Dis. 2011;15(11):1461-i.

15. Shetty N, Shemko M, Vaz M, D’Souza G. An epidemiological evaluation of risk factors for tuberculosis in South India: a matched case control study. Int J Tuberc Lung Dis. 2006;10(1):80-6. 